\title{
Suburbanisation and Suburbanisms - Making Sense of Continental European Developments
}

\author{
Markus Hesse $^{1}$ (D) $\cdot$ Stefan Siedentop ${ }^{2}$ (i) \\ Received: 23 October 2017 / Accepted: 30 January 2018 / Published online: 12 February 2018 \\ (c) Springer-Verlag GmbH Deutschland, ein Teil von Springer Nature 2018
}

\begin{abstract}
This paper provides a brief overview of recent developments and debates concerned with suburbanisation in continental Europe. While current discourses in urban research and practice still focus on processes of reurbanisation and the gentrification of inner-city areas, suburbia continues to exist and thrive. Depending on the definition applied, suburban areas still attract a large share of in-migration and employment growth in cities of the developed countries. Given that popular meta-narratives on suburbia and suburbanisation are often spurred by, or refer to, North American suburban studies, we take a different perspective here, one based on continental European trajectories of development in and across city-regional areas that are considered to be suburban, and on social processes that are associated with suburbanisation (suburbanisms). Thus, we aim to avoid a biased understanding of suburbia as a spatial category, which is often considered mono-functional, non-sustainable, or in generic decline. Instead, we observe that suburban variety is huge, and the distinction between urban core and fringe seems to be as ambiguous as ever. The paper, which also introduces the theme of this special issue of "Raumforschung und Raumordnung I Spatial Research and Planning", bundles our findings along four themes: on suburbia as a place of economic development, on the shifting dynamics of housing between core and fringe locales, on the life-cyclic nature of suburbanisation, and on strategies for redevelopment. Finally, we discuss certain topics that may deserve to be addressed by future research, particularly on the European variant of suburbanisation and suburbs.
\end{abstract}

Keywords Suburbanisation $\cdot$ Suburbs $\cdot$ City regions $\cdot$ Europe

Prof. Dr. Markus Hesse

markus.hesse@uni.lu

Prof. Dr. Stefan Siedentop

stefan.siedentop@ils-forschung.de

1 Institute of Geography and Spatial Planning, University of Luxembourg, 11, porte des Sciences, 4366 Esch-sur-Alzette, Luxembourg

2 ILS - Research Institute for Regional and Urban Development, Brüderweg 22-24, 44135 Dortmund, Germany 


\section{Suburbanisierung und Suburbia im kontinentalen Europa - eine Standortbestimmung}

\section{Zusammenfassung}

Dieser Beitrag gibt einen Überblick über aktuelle Entwicklungen und Diskurse zur Suburbanisierung im kontinentalen Europa. Gehen landläufige Wahrnehmungen in Planung und Forschung immer noch von einer allgemeinen Tendenz der Reurbanisierung aus, hält der Entwicklungsdruck auf suburbane Räume weiter an. Je nachdem, wie suburbane Räume jeweils definiert und abgegrenzt werden, haben sie weiterhin einen großen Anteil an der Bevölkerungsentwicklung, an Migration und Wirtschaftswachstum. Populäre Zuschreibungen über die Monofunktionalität, die Nicht-Nachhaltigkeit bzw. den Niedergang von Suburbia basieren vielfach auf Forschungen zu nordamerikanischen Stadtregionen. Unsere Perspektive richtet sich dagegen auf Entwicklungen in kontinentaleuropäischen Stadtregionen. Hier ist die Bandbreite suburbaner Entwicklungen relativ groß, die Unterscheidung von Peripherie und Kernstädten dagegen weniger eindeutig als zuvor. Unser Beitrag, der auch in den Themenschwerpunkt dieser Ausgabe von „Raumforschung und Raumordnung I Spatial Research and Planning" einleitet, skizziert aktuelle Entwicklungen über den Stellenwert suburbaner Räume anhand von vier Beobachtungen: mit Blick auf ihre wirtschaftliche Bedeutung, zum Wohnen im Kern und am Rand, zum lebenszyklischen Wandel suburbaner Gebiete sowie zu Strategien ihrer Erneuerung. Vor dem Hintergrund dieser Beobachtungen werden abschließend aktuelle Herausforderungen für die künftige Forschung und Praxis benannt, speziell mit Blick auf europäische Verlaufsformen von Suburbanisierung und Suburbia.

\section{Schlüsselwörter Suburbanisierung · suburbane Räume · Stadtregionen · Europa}

\section{Introduction}

While current discourses in urban research and practice tend to focus on processes of reurbanisation and the gentrification of inner-city areas, suburban areas are still a vital part of many city regions, at least in a majority of the developed countries. "The world is increasingly urban, and the urban world is increasingly suburban" (Klausen/Røe 2012: 1). As studies on suburbia and suburbanisation often emphasise North American or Anglo-Saxon debates and developments, we prefer to take a distinct continental European perspective on this topic. Given the importance of suburbanisation, particularly in North America, most notably the United States, it certainly follows an empirical rationale that a large share of recent research publications has been devoted to Anglo-American perspectives (see, e.g., Modarres/Kirby (2010) and other contributions in a theme issue of "Cities"; Grant/Nelson/Forsyth et al. (2013) in an "Interface" in "Planning Theory and Practice"; or Nijman (2015) and other contributions in "Environment and Planning A"). However, European developments also deserve closer inspection in terms of this subject matter. In a recent edited volume, Phelps (2017) and fellow co-authors assumed a genuinely European perspective on suburbs and suburbanisation, such as that which we aim to take here. When Phelps (2017: 6f.), in the editor's introduction to that volume, juxtaposes 'old' Europe and 'new' suburbanisation, he also considers Europe to be "a good place to observe these processes of suburbanisation". He particularly emphasises that the relative affluence of European countries has produced a certain variety of suburbs and suburbanisms. Moreover, he shares the view that suburbanisation is still an ongoing process and exhibits a degree of complexity that makes it, against the historically specific background of European urbanisation, an ideal subject of inquiry. This is also the starting point of our paper.

In this context, the remainder of our paper is organised as follows. The next section provides a brief overview of the current state of suburbanisation in continental Europe, based on the assessment of a variety of secondary sources. The subsequent section reflects the shifting discourses on suburbia in Europe that seem to be altering, as the role of suburban areas in the urban and city-regional context is about to change. We then summarise our observations in five points that indicate how suburbanisation and suburbia have changed in continental Europe in recent times. These characteristics distinguish between more traditional and more recent approaches to suburbia, emphasising i) work and economic development, in addition to the traditional focus on housing and residential populations; ii) the co-existence of suburban patterns of development evolving in core urban areas and more urbanised forms of development that can be observed on the fringes; iii) maturity and temporal shifts instead of a fixed status that leaves suburbia in a sort of dead-end of urban development; and vi) peculiar forms of governance in suburban communities that not only focus on serving these communities' interests but have the potential to shape the city region. A short outlook closes this paper, outlining some challenges for governing suburbia and related conclusions for future research. 


\section{European suburbanisation - still ongoing?}

Since the 1960s, the European urban landscape has been deeply transformed by forces of residential and economic de-concentration (Fielding 1982; Hesse/Schmitz 1998; Bontje 2001; Caruso 2001; Johansson/Rauhut 2002; Siedentop/Kausch/Einig et al. 2003; Gordon/Cox 2012). Notwithstanding the considerable sub-continental diversity of context-dependent development patterns, the suburbanisation of population and economic activity is still a general and powerful characteristic of urban restructuring in continental Europe (Kabisch/Haase 2011; Ravetz/Fertner/Sick Nielsen 2013; Salvati/Morelli 2014; Wolff/Wiechmann 2017; Hilal/Legras/Cavailhès 2018 for France).

As stated for the United States, Canada and Australia (Davison 1995; Duany/Plater-Zyberk/Speck 2000; Gordon/ Janzen 2013), many European countries also entered the $21^{\text {st }}$ century as 'suburban nations', in the sense that the majority of their populations had become suburban by the 1980s or 1990s. The continuous movement of people, businesses and workplaces from more to less dense, from central to remote locations, has considerably changed our view of the European City - in morphological, functional, political and ideological ways. Urban research has addressed this multidimensional transformation from different perspectives - among others, the change in land use patterns and landscapes (Antrop 2004; Siedentop/Fina 2012; Salvati/ Carlucci 2015; European Environment Agency 2016), the regionalisation of housing and employment markets connected to changing mobility patterns (Schwanen/Dieleman/ Dijst 2004; Muñiz/Garcia-López/Galindo 2008; GarciaLópez/Muñiz 2010; Guth/Siedentop/Holz-Rau 2012) and intra-regional economic networks (Hall/Pain 2006; Thierstein/Lüthi/Kruse et al. 2008) and the emergence of new forms of metropolitan policy making (OECD 2017; see Carr/McDonough 2018).

Most analysts consider (sub)urbanisation in Europe and North America as predominantly convergent, derived from the observation of common development trends, particularly the emergence of a less dense, poly-nucleated urban structure or even a dispersed distribution of people and jobs over a spatially extended, 'edgeless' and 'sprawling' urban field (Richardson/Bae 2004; Gordon/Cox 2012). However, the hypothesis of an 'Americanisation' of European city regions is challenged by stark differences in the direction and intensity of urban restructuring, which is an outcome of both urban-regional trajectories and their political steering. In particular, "the age of European urbanisation and nation states is sometimes contrasted to the youth and vigour of North American settlements" (Phelps 2017: 10). European city regions are still much more centralised and concentrated than their counterparts in the United States and Canada. Inner city areas have not been affected by out-migration at a rate comparable to that found in metro areas in the United States. Thus, the employment and residential densities in Europe's urban cores are still considerably high (Riguelle/Thomas/Verhetsel 2007; GarciaLópez/Muñiz 2010). Moreover, the outer boundaries of commuting hinterlands in European city regions seem to be less extended than in the US because forms of 'exurban' development (Taylor 2011) have occurred to a much lesser extent. The reasons for this may be linked to higher transportation costs in most European countries and - at least in some EU member states - relatively restrictive growth management and compact-city policies (Bontje 2001; Fertner/Jorgensen/Sick Nielsen et al. 2016).

Moreover, recent empirical studies have provided evidence of a relative relaxation of suburbanisation or even a reversal towards an urban renaissance in some European countries at the beginning of the $21^{\text {st }}$ century (Turok/Mykhnenko 2007; Turok/Mykhnenko 2008; Wolff/ Wiechmann 2017; see Figure 1). This work reported on the regrowth of central cities after a longer period of decline (Le Galès/Zagrodzki 2006; Rérat 2012; Wolff/Haase/Haase et al. 2017), driven primarily by younger, better educated and higher-income people, but families were also at least partially involved in the process of residential densification of the urban cores (Buzar/Ogden/Hall et al. 2007; Frank 2018; Siedentop/Zakrzewski/Stroms 2018). Although signs of a recovery of inner city areas (Bourne 1992; Frey 1993; Sohmer/Lang 2001) have also been observed in the US and Canada, commentators emphasise the unbroken trend of suburbanisation in North America (Wilson/Plane/Mackun et al. 2012; Florida 2017; Maciag 2017).

Observing North American and European trajectories of urban change, Phelps, Wood and Valler (2010: 369) indicate 'temporal disparities' in terms of the pace and timing at which change has proceeded in different contextual settings. Following this line of argumentation, urbanisation or suburbanisation is universal but might occur in a timeshifted form, depending on local and regional context conditions. Mazierska's and Rascaroli's (2003) claim of 'dimensional disparities' is somewhat different, as they refer to 'softer', less extensive changes in urban structures in European city regions, compared with their US counterparts. We believe that much more comparative empirical research is needed to validate statements about the 'Americanisation' of European urban areas or a specific European mode of urban change and (suburban) policy making (see for example Charmes/Keil 2015).

More comparative research is also needed of the social restructuring in city regions. In the US context, a powerful narrative is being told about the suburbanisation of poverty as the outcome of gentrification and the displacement of the urban poor from central locations and/or the physical decline of first ring housing stocks. While such 


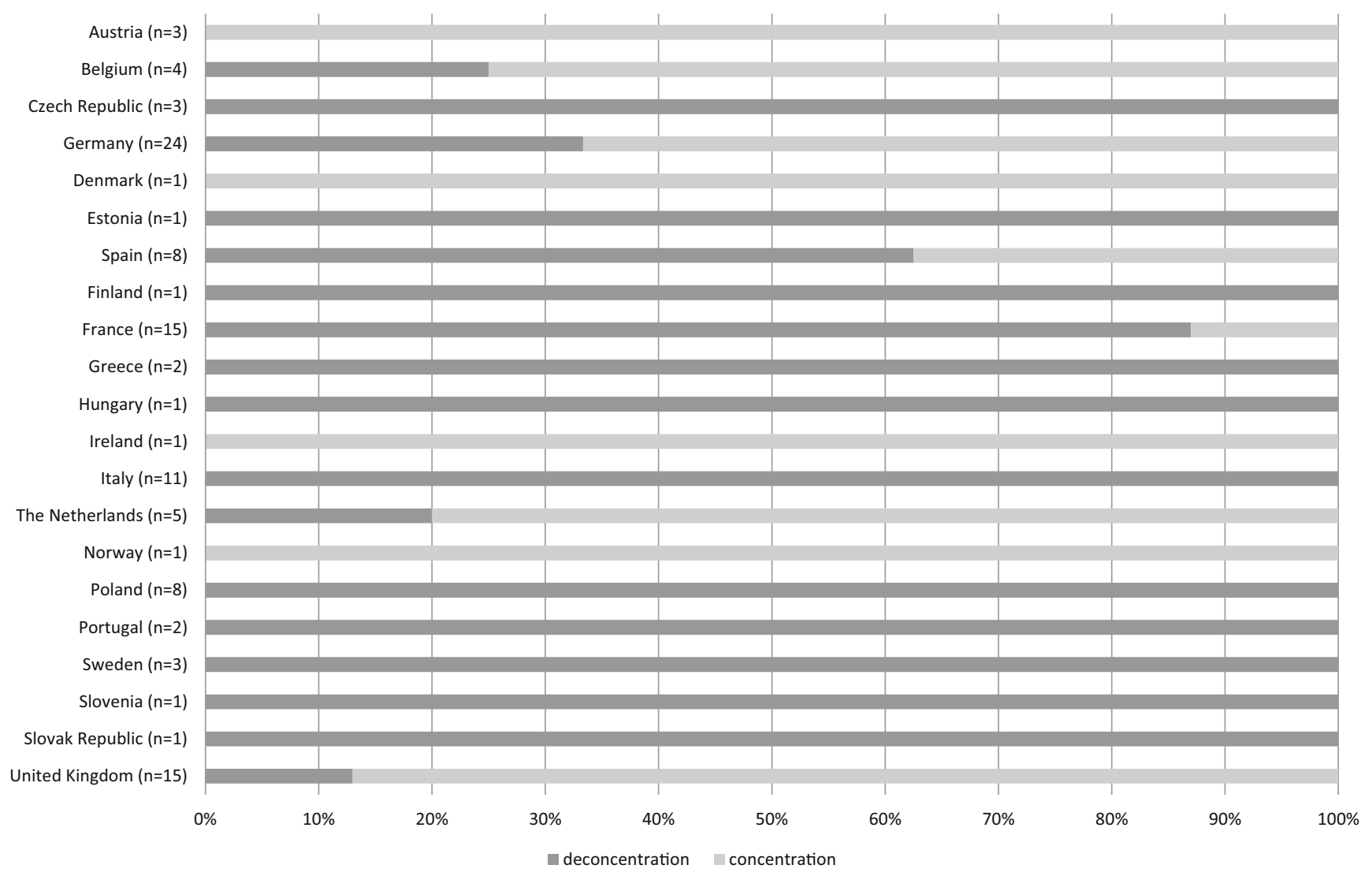

Figure 1 Share of metropolitan regions with intra-regional population de-concentration (a declining share of the core city to the total metropolitan population) and concentration (an increasing share of the core city to the total metropolitan population) between 2000 and $2014 .{ }^{1}$ Source: authors' calculations based on the OECD metropolitan database

patterns of suburban decline have been extensively debated in the North American and Australian contexts (Kneebone/ Garr 2010; Cooke/Denton 2015; Kneebone/Nadeau 2015; Randolph/Tice 2017), relatively few investigations have been carried out for Europe's city regions (Seidel-Schulze/ Dohnke/Häußermann 2011; Hochstenbach/Musterd 2017). Available studies provide evidence of a certain suburbanisation of low-income households, but this has occurred in a rather moderate way. Indications of a social inversion in large metropolises as Ehrenhalt (2012) hypothesised for certain US central cities are not on the horizon. In Germany, the on-going demographic shrinkage of remote suburban areas is seen as a driver of decline, but this has not yet been associated with a dispersion of deprivation and poverty in the suburban realm (Fina/Planinsek/Zakrzewski 2009; Berndgen-Kaiser/Bläser/Fox-Kämper et al. 2014).

\footnotetext{
1 The figure displays the proportions of regions with a declining (deconcentration) and rising (concentration) share of central city population to the total metropolitan population. The data show strong disparities between Eastern and Western Europe. All metro areas of post-socialist countries display suburbanisation, whereas many Western European regions demonstrate a clear break from the past, as a majority of regions witnessed a trend towards concentration.
}

Beyond a transatlantic perspective, differences within continental Europe demand more scholarly attention (Johansson/Rauhut 2002). Given the complex interplay of varying socio-cultural practices, economic structures, institutional settings, demographic patterns or state intervention and planning cultures, striking differences in urbanisation across Europe cannot be surprising. In terms of morphological and functional patterns as well as timing and pace, scholars have noted a variegated spectrum of trajectories within continental Europe, particularly between Western and Eastern Europe but also between regions in Northwest and Southern Europe (Petsimeris 2002; Hirt 2006; Kabisch/ Haase 2011; Siedentop/Fina 2012; Salvati/Morelli/Rontos et al. 2013; Salvati/Morelli 2014; Schmidt/Fina/Siedentop 2015). Such differences include the direction and scale of metropolitan restructuring between the poles of an ongoing suburbanisation (in Eastern Europe and in major parts of Southern Europe) and a strong re-concentration of residents and jobs in some Western European countries (see Figure 1). However, too few studies have empirically addressed such differences and traced what factors might account for them. 


\section{Shifting discourses on European suburbia}

From a socio-economic point of view, suburban areas have always represented more than just a certain category of space or territory, a place on the city's fringes and beyond. Suburbia was, on the one hand, subject to the collective projection of millions of people in search of the 'good life'. What started as a primarily 'burgeois' utopia (Fishman 1987) became a mass phenomenon after World War II (Silverstone 1997). Equipped with the family house with a garden and a car, the suburbanites hoped to escape from the inadequacies and conflicts of urban space and find a new home on the outskirts or beyond the city. Metaphors such as 'city flight' were popular at that time. As an attribution, however, they overlooked the continuing popularity of life in the suburbs and on the outskirts of the city.

On the other hand, suburbanisation from the perspective of the professional communities (namely researchers and planners dealing with suburbs) was long associated with problems and burdens and assessed critically. The relevant literature is full of corresponding examples and references. In the scholarly world, they were subject to bitter controversy within city planning, spatial research and other social sciences. Positions oscillated between the polarised models of the European city on the one hand and the urban landscape on the other hand (normatively also approached as the apparent 'Americanisation' of the cities). In her excellent study "How Hell Moved [...] to the Suburbs", Nicolaides (2006) discussed the 'perceptual migration' of the bad to the suburbs, after which the suburbs were no longer conceived of as the city's benevolent partners but their destroyers. Quoting Mumford (1921: 45): "Suburbia - that vast and aimless drift of human beings, spreading in every direction about our cities, large and small - demonstrates the incapacity of our civilization to foster concrete ways and means for living well". Such a critical singleminded position was maintained and further developed during the mass-suburbanisation of the 1960s and 1970s, and it was still prevalent during the 1980s and 1990s, particularly in what we consider 'critical' urban studies and planning. The conventional image of suburbia as a dull, boring place emerging from standardised ways of life practised by the suburban middle class was given broad coverage in the media and thus in major parts of popular culture. In an article in the "Atlantic", a monthly magazine that is quite well known in the US and the English-speaking world, Christopher Leinberger, a real estate expert and researcher, wrote about suburbs as "the next slum" (Leinberger 2008). This statement received an astonishing amount of feedback. His argument is that a critical assessment of the suburbs is justified more than ever, in response to shifting socio-economic framework conditions. Demographic change was identified as a major driving force behind these processes, particu- larly the aging of the baby-boomer cohorts and thus of the single-family housing areas of the post-World War II era. In a similar vein, Nelson (2013: 393) argued for a fundamental plan-led transformation of American suburbs as a response to changing demographics, labour markets and housing preferences: "If planners and policy-makers heed emerging market trends and preferences, America's suburbs could change dramatically". Related claims were made in the late 2000s by commentators in Europe, mainly stating that suburbia would run out of its "personnel", as a consequence of a changing, somehow post-Fordist division of labour (Häußermann/Läpple/Siebel 2008: 370). The same applies to a changing regime of housing and real estate markets and the expected future increase in energy prices. Such factors could seriously question the mechanisms that once constituted suburbia - particularly cheap mobility and thus could make life in dispersed, suburban areas increasingly unattractive (Hesse/Scheiner 2007).

The extent of this criticism, however, was obviously exaggerated. It is neither in line with the sustaining attraction of life in suburbia for many of its inhabitants, nor is it backed by proper research that takes a look at suburbia from within, rather than addressing its shortcomings from the central city's perspective. Starting already a decade earlier, in the second half of the 1990s, new approaches were formulated in the suburbanisation discourse in Germany and new priorities were set, mainly as a result of the suggestions made by the work of Sieverts (1997) in the context of the "Zwischenstadt". This sort of pluralised debate took place not least in response to the continuing rise in the significance of this category of territory. There are three different accentuations that have shaped the discourse. First, various urban functions have been involved in the suburbanisation process, which is increasingly fuelled by the mobility of trade, leisure, industry and services. Second, analyses of the actors and their behavioural interests were undertaken, which resulted in numerous migration motivation studies and milieu analyses. Third, in the context of the city classified as 'post-modern' or 'post-suburban' (see below), a change in perspective with regard to the traditionally critical assessment of suburbanisation occurred: suburban areas were no longer viewed as one-sidedly negative, but in a differentiated way.

This re-valuation of suburbia evolved both in North America and Europe (cf. Keil 2013, for the former, Clapson 2003 and Harris/Larkham 1999, for the latter). It was undertaken for several reasons, starting with the fact that this part of the city region represents an undeniable reality that cannot be ignored as such. Suburban spaces are, first and foremost, an actually existing element of the urban regions, regardless of whether they are desired, and they certainly have a concrete, material fundament. Second, they become increasingly similar in the course of their urbanisa- 
tion. The separation between the city and the surrounding area, which has for a long time been key to the definition of suburbia, seems to be less clear. These phenomena raise questions and challenges to urban policy, as was previously the case for the inner cities or their core areas. Third, what appears as a prime criticism of suburbia unfolds from rather essentialist thought, based on a direct association between the form of the built city and the state of society, which effectively views people's attitudes and practices as derived from patterns of dwelling and settlement. For it is part of the basic understanding of a differentiated theory of spatial research that suburbanisation is not the problem, but that attitudes, preferences and decisions are the guiding principle of the specific actions of users in a social context.

How short-lived public and even professional estimations of the poor prospect of suburbanisation can be, is demonstrated by the most recent twists and shifts in the development of suburbia. Just a decade after another round of farewells questioned the future of suburbia, the related arguments have proven to be not only massively simplistic but also de facto overrun by another revival of suburbia, which is now increasingly considered as an important reserve for constructing more housing in metropolitan areas (Adam 2017). Suburbs have neither vanished nor lost their attraction as a place for living and working. In a changing, dynamic environment, such apologetic claims seem to be far too general and exaggerated to effectively do justice to the variety and complexity of what has emerged in city regions and in particular on their fringes (Bourne 1996; Kuhn 2002).

\section{Observations from 'new' suburbanisation studies}

The first of our observations sheds light on the further development of suburbia as a place not only for housing but also for work and economic activities. In this context, suburban areas develop as complementary and, at least in part, as independent economic spaces within the context of the city region. This phenomenon certainly borrows from US/UK debates, with post-suburban developments at centre stage. In fact, suburbia has recently emancipated itself as its own space of settlement that can no longer be conceptualised as a subordinate part of large cities (Kloosterman/Musterd 2001; Danielzyk/Münter/Wiechmann 2016; Nüssli/Schmid 2016). The de-coupling of suburban areas from the predominant core city has frequently been framed under the umbrella term 'post-suburbia' (Phelps/Parsons/Ballas et al. 2006). The emergence of this further period within the lifecourse of suburbia can be considered as a globally relevant phenomenon generated by forces of economic and social restructuring (Hall/Pain 2006). Nevertheless, with a view to the obvious transatlantic diversity of spatial configurations, it seems important to discuss whether there is a specific European or even sub-continental 'mode' of post-suburban change. It was, for example, noted that new centralities in remote suburban places - so called edge-cities (that were seen as one of the key characteristics of postmodern urbanism in the North American context; see Dear/Flusty 1998) - are mainly missing in Europe's suburban landscape (see, for example, Bontje/Burdack (2005) for Paris and Randstad, Helbich (2012) for Vienna or Krehl/Siedentop/Taubenböck et al. (2016) for Cologne, Munich, Frankfurt and Stuttgart). Although a sub-centring of office space, retail, leisure facilities and housing can be seen as a constitutive element of the European post-suburban landscape, the evolved economic poles are "not mere copies" of US-style edge cities, as Bontje and Burdack (2005: 317) concluded for the Paris and Randstad regions. They consider such built spaces as a "typically European variation of the original edge city model".

European-style sub-centres are usually smaller than their North American counterparts (in terms of the amount of built floor space), mostly located in close proximity to the central city rather than at remote ('edge') locations, and they represent rather complementary sites instead of alternatives to the traditional downtowns as the main economic hubs (Bontje/Burdack 2005; Knapp/Volgmann 2011; Carr/ McDonough 2018). One explanation for this refers to the much larger amount of public involvement in the planning process of suburban centres in countries such as France and the Netherlands (Bontje/Burdack 2005). Furthermore, less rigid zoning practices in Europe, compared to the US experience, have often been stressed as relevant contextual factors responsible for a transatlantic divergence in spatial urban structure and urban form (see Hirt 2012). While residents and their residential preferences have long been identified as strong drivers of the process of suburbanisation, other influences have been discussed to a much lesser extent, such as the supply side of the housing market or job opportunities for the residents.

Suburban developments are increasingly shaped by the combined effects of residential preferences and employment concentration, and the debate on the nature and state of such suburban areas is developing dynamically. In the context of deindustrialisation processes in peripheral areas, where it seems difficult to create services sector jobs for compensation, Hilal, Legras and Cavailhès (2018) examine the role of employment concentration within centres and sub-centres. This is an important but often overlooked factor that may be able to explain current characteristics of suburbanisation. An increase in the pace of suburbanisation is then not only driven by the increase in population, following the standard residential push and pull factors, but also by the decrease in jobs available in these periph- 
eral areas. Municipalities losing jobs can flip into a state of dependency towards the job-providing areas, becoming 'suburban municipalities' in the statistical sense, without gaining any population. To examine this phenomenon, the authors combine theoretical and empirical approaches based on nationwide data in France. Understanding the drivers of suburbanisation at stake is crucial to propose relevant policy guidance. Indeed, the impacts of an increase in suburbanisation that is due to growth in population differ from those of suburbanisation due to a reclassification of the municipalities following the job concentration process. In particular, the residential or transport sectors will not be affected in the same way.

Our second observation that sheds a new light on suburbs and suburbanisation processes relates to housing situated between fringe and core localities, triggered by the selective use and related design of separate pockets of housing units. This leads to the territorial paradox based on a switching of traditional categories of location choice: it reveals fringelike behavioural patterns emerging in the centre and denser city-centre-like developments at the edges (see Walks 2013 and Frank 2018). In many Western urban regions, suburbanism has not only left its mark on the outskirts of the cities but increasingly shapes the inner cities as well. What has been framed as a sort of 'renaissance of the inner cities' as places to live and work in indicates a profound twist and turn in urban development. The penchant for city life is particularly true of high earners and the creative milieu in many parts of the world. Particularly remarkable here is the fact that, after decades of suburbanisation, young families who could indeed afford their own homes in the suburbs are deliberately aiming to stay in or return to the city.

Efforts to re-develop inner cities and neighbourhoods to meet the specific demands of middle-class families can be witnessed almost everywhere. New family settlements are mushrooming, especially on former brownfields at central urban locations which were given up by their previous occupiers (such as industry, military or logistics). These developments vary considerably in terms of size, style, furnishings, price, and, hence, the target group. They range from basic to luxurious and, typologically, from the still infrequent townhouse developments to collaborative building projects. These concepts clearly target active, mobile and affluent middle-class families, particularly of the bourgeois-liberal and leftish green-alternative milieus. Drawing on international literature and multi-year research on the new family enclaves in various German cities (notably in Berlin and Dortmund), Frank (2018) argues that the apparently middle-class families' "return" to the inner cities is best interpreted as "inner-city suburbanism". The paper reveals that many of the new middle-class family islands are systematically reminiscent of traditional suburbia: privately-owned single-family homes with (small) gardens; social, cultural and age homogeneity; emphasis on privacy and community with a focus on family life; clear architectural and social demarcation from the surrounding urban environment; and protection against the dangers and uncertainties of city life. In this light, it is proposed that that the new family enclaves of the post-Fordist service society should be described as the functional equivalents of the suburban settlements of the industrial society. The return of middle-class families to the city is above all rendered possible because the families - as a joint force and with the powerful backing of politicians, planners, and investors - succeed in transferring elementary forms and functions, norms and values of suburban life to the towns.

Our third observation is concerned with generational change in post-World War II suburbia (Hesse/Polívka/ Reicher 2018). As mentioned earlier, changing social and economic conditions are no longer exclusive to inner-city areas but increasingly take place in suburban areas as well. Although initially designed for growth only and thus also actually prepared for expansion rather than revitalisation, many suburban areas with older housing stocks and aging infrastructure facilities are challenged by decline as a significant part of their everyday reality (see above). While the initial suburban trajectory was driven by steady growth, many suburbs have in fact experienced shifting development dynamics over time. Accordingly, Hesse, Polívka and Reicher (2018) face the question of how to approach the temporarily differentiated development dynamics of suburban spaces within a systematic, conceptual framework for analysis. The temporal variation and trajectory analysis is key to that debate. The paper focuses on the integration of the particular phases and cycles into a broader context of the suburban system and - as far as possible describes interdependencies of trigger factors and of the local and regional frameworks. This distinguishes the approach from that of a static spatial analysis. Such phases contain, in most cases, the growth, maturity, transition and resilience of suburban areas. Resilience describes the capability of a system to encounter decline or even to reach a development turn. The phases develop into cycles when temporal periodic changes occur, following a certain logic, which is determined by demographic, socio-economic or urban design-related factors and strategies. When the development of suburban areas is temporally distinct, the strategies that municipalities set up to realise their goals must adapt. There seems to be an equally broad range of strategies aiming for growth, consolidation and adaptation, of which any one can be interpreted as an attempt to do justice to the differentiated times (and not only spaces) of suburbanisation.

A fourth observation addresses the intensifying debate over a planned transformation of suburbia, which is often referred to as 'smart growth' (Ye/Mandpe/Meyer 2005) 
and 'retrofitting' (Dunham-Jones/Williamson 2009) or 'refitting' (Jessen/Roost 2015). On both sides of the Atlantic, scholars, planners and policy makers are discussing strategies and policies for adapting suburban areas to stated macro-scale changes in demographics, markets and housing preferences. The transatlantic common ground of such claims is the above-mentioned perception of a 'decline' or even 'crisis' of suburbia (or at least some parts of it) due to processes of demographic aging, aging housing stocks and infrastructure in need of renewal. Mostly, residential densification and diversification of housing supply, the creation of mixed use and walkable neighbourhoods, and the installation of rail-based transportation infrastructure ('transit-oriented development') are seen as appropriate means of a specifically suburban sustainability transition (Filion/McSpurren/Appleby 2006; Ewing/Bartholomew/ Winkelman et al. 2008; Nelson 2013).

Beyond these parallels, clear differences in the retrofitting discourses are obvious. First, this refers to divergent growth pressures in North America and Europe and the often radically different morphological and functional patterns in the suburban realm - in terms of built densities, infrastructure provision or the social composition of suburban neighbourhoods. Siedentop (2015) noted that the still relatively low residential and employment densities in North American suburbs discourage the installation of high-quality transit. In contrast, in many European regions, low growth projections for suburban areas undermine the cost-effectiveness of infrastructure investments. Second, the regimes, cultures and actor networks of planning and decision making and the forms of state intervention demonstrate large variation, and this holds true from both a transatlantic and an interregional European view. However, not much empirical research has been carried out to better understand the directions and internal logics of retrofitting programmes, the political process of their implementation and their performance with respect to outcomes and impacts.

Our fifth observation concerns the political and governance practices that are prevalent in suburbia, both with respect to the micro- and meso-levels of suburban communities and also the role they play within the wider realm of the metropolitan regions. The political governance of urban fringes has rarely been covered by research so far, particularly not as an issue in its own right; it has rather been emphasised from the core cities' perspective. Effectively, urban peripheries and suburban areas have absorbed a major part of the contemporary expansion of urban-regional settlements. However, the institutional conditions for an associated steering or governance "have not yet matured to address the socio-economic problems of the periphery" (Salet/ Savini 2015: 448). Carr and McDonough (2018) address the particular conditions of post-suburban urbanisation in a Western European financial capital. The empirical basis of their paper is drawn from an exploration of initiatives in the region of Glatt Valley, Switzerland, that seek to achieve spatial integration. Glatt Valley is a politically defined area that extends from the city of Zurich towards the airport, including 15 micro- and smaller-sized municipalities. It has absorbed much of the region's recent growth pressure and has produced an archetypical case of high-density, business- and services-driven suburban space. This trajectory has forced municipalities to coordinate housing, transport and economic activity beyond administrative borders. In the case of Glatt Valley, the urbanisation of a previously suburban area was driven by infrastructure consolidation towards integrating functional pathways and optimising capital accumulation - an urbanisation process that was primarily set in place to attract, assist and care for business development. Ironically, given the dedication to integration, this urbanisation contributed to further fragmentation and social stratification, both at the level of the city region and, to a lesser extent, within Glatt Valley. According to the authors, the results also reveal post-suburban forms that are place-specific and path-dependent insofar as they are driven by specific governance arrangements undertaken locally, not at the core of the city region. Thus, the results shed new light on the peculiar making of suburbia by agents situated within and beyond the suburban communities.

\section{Policy challenges and avenues for future research}

Today's suburbs are socially and culturally more diverse, increasingly dense and much better provided with highly qualified jobs, urban services and amenities than in earlier decades. For good reason, scholars have long observed challenges that demand action. Car-dependent lifestyles and low standards of energy efficiency make suburbs vulnerable to rising energy prices. Changing demographic patterns and shifting consumer preferences demand a diversification of housing markets. Socially selective migration processes ('suburbanisation of poverty') and growth management practices have recently led to increasing rates of economic and ethnic segregation within suburban areas. However, scholarship that predicts the demise of suburban areas as a consequence of socio-economic transformations and changing lifestyles is obviously misguided. This review of current developments and also the subsequent papers presented in this theme issue of the journal may illustrate that suburbanisation is far from running out of resources but is still thriving in Europe. The reasons for its prevalence are manifold, located both within suburbs and at the larger cityregional scale.

When considering the rising degrees of variation, maturation and complexity that seem to signify contemporary 
suburbia, some implications for research and practice can be identified. Defining and making sense of suburbs and suburbanisation (including their ex-urban or peri-urban variants) remains as a first, more conceptual challenge. Here, Richard Harris' (2010) trilogy of properties of suburbia comes into play as a popular frame often referred to when defining or characterising suburbs: according to his definition, a suburb compared to a central city is, first, located at a peripheral place; second, has lower densities than the built fabric of the core city; and, third, is characterised by newness. In particular, the third dimension can and must be challenged once the suburb in question comes to maturation. At some time in their course of life (or lifecycle), suburbs are no longer new but change or become urban. As soon as they represent a vital part of the city region, their urbanisation brings about the distinct challenge of coping with age and maturation. The above-discussed agendas of 'smart growth' or 'retrofitting' offer a discursive corridor in this sense.

Second, the question is what the proper place for suburbia can be in city-regional policy. Urban-regional policies need to develop an idea of what suburbia should look like in the future, what benefits it may offer, and for whom. For this sort of quality strategy for suburban areas, collective activities should be undertaken to establish or ensure, for example, a place of residence as a functioning social space. Such activities need, finally, to be transformed into systematic approaches for monitoring the local and regional real estate markets. Small-scale territorial data with information on the age of the population, life cycles and development dynamics of the districts can provide early information on existing or expected problems and allow planning to prepare for short-term crises and develop medium-term strategies. Communicative methods, in particular in addressing citizenship and the public and establishing networks of actors, can be an important prerequisite for success. This would not be unfamiliar terrain for urban development policy, given the decades of experience in many European countries with inner-city urban renewal. However, applying renewal to the fringe is different, and conflicts of interest are to be expected whenever and wherever resources are limited. From the municipal point of view, competing priorities are already being set that address problems in the inventory of core urban areas. Thus, the call to extend urban re-development and planning policies to suburbia might be challenged by the stakeholders of the central cities and thus become quickly contested.

Acknowledgements We are grateful to the Editors of Raumforschung und Raumordnung I Spatial Research and Planning for their interest in this special issue. We also thank the anonymous referees for their insightful comments on earlier versions of the papers. The usual disclaimers apply.

\section{References}

Adam, B. (2017): Wachstumsdruck in deutschen Großstädten. Bonn. = BBSR-Analysen KOMPAKT 10/2017.

Antrop, M. (2004): Landscape change and the urbanization process in Europe. In: Landscape and Urban Planning 67, 1-4, 9-26. https:// doi.org/10.1016/S0169-2046(03)00026-4

Berndgen-Kaiser, A.; Bläser, K.; Fox-Kämper, R.; Siedentop, S.; Zakrzewski, P. (2014): Demography-driven suburban decline? At the crossroads: mature single-family housing estates in Germany. In: Journal of Urbanism 7, 3, 286-306. https://doi.org/10.1080/ 17549175.2013 .879456

Bontje, M. (2001): Dealing with Deconcentration: Population Deconcentration and Planning Response in Polynucleated Urban Regions in North-west Europe. In: Urban Studies 38, 4, 769-785. https://doi.org/10.1080/00420980120035330

Bontje, M.; Burdack, J. (2005): Edge cities, European-style: Examples from Paris and the Randstad. In: Cities 22, 4, 317-330. https://doi. org/10.1016/j.cities.2005.01.007

Bourne, L.S. (1992): Population Turnaround in the Canadian Inner City: Contextual Factors and Social Consequences. In: Canadian Journal of Urban Research 1, 1, 66-89.

Bourne, L.S. (1996): Reinventing the suburbs: Old myths and new realities. In: Progress in Planning 46, 3, 163-184. https://doi.org/10. 1016/0305-9006(96)88868-4

Buzar, S.; Ogden, P.; Hall, R.; Haase, A.; Kabisch, S.; Steinführer, A. (2007): Splintering Urban Populations: Emergent Landscapes of Reurbanisation in Four European Cities. In: Urban Studies 44, 4, 651-677. https://doi.org/10.1080/00420980601185544

Carr, C.; McDonough, E. (2018): Integrative Planning of Post-suburban Growth in the Glatt Valley (Switzerland). In: Raumforschung und Raumordnung I Spatial Research and Planning 76, 2. https:// doi.org/10.1007/s13147-016-0403-x

Caruso, G. (2001): Peri-urbanisation: the situation in Europe. A bibliographical note and survey of studies in the Netherlands, Belgium, Great Britain, Germany, Italy and the Nordic countries. Louvainla-Neuve.

Charmes, E.; Keil, R. (2015): The Politics of Post-Suburban Densification in Canada and France. In: International Journal of Urban and Regional Research 39, 3, 581-602. https://doi.org/10.1111/14682427.12194

Clapson, M. (2003): Suburban century: Social change and urban growth in England and the United States. Oxford.

Cooke, T.J.; Denton, C. (2015): The suburbanization of poverty? An alternative perspective. In: Urban Geography 36, 2, 300-313. https://doi.org/10.1080/02723638.2014.973224

Danielzyk, R.; Münter, A.; Wiechmann, T. (eds.) (2016): Polyzentrale Metropolregionen. Lemgo. = Planungswissenschaftliche Studien zu Raumordnung und Regionalentwicklung 5.

Davison, G. (1995): Australia. The first suburban nation? In: Journal of Urban History 22, 1, 40-74. https://doi.org/10.1177/ 009614429502200103

Dear, M.; Flusty, S. (1998): Postmodern Urbanism. In: Annals of the Association of American Geographers 88, 1, 50-72. https://doi. org/10.1111/1467-8306.00084

Duany, A; Plater-Zyberk, E.; Speck, J. (2000): Suburban nation: the rise of sprawl and the decline of the American Dream. New York.

Dunham-Jones, E.; Williamson, J. (2009): Retrofitting Suburbia. Urban Design Solutions for Redesigning Suburbs. Hoboken.

Ehrenhalt, A. (2012): The great inversion and the future of the American city. New York.

European Environment Agency (2016): Urban sprawl in Europe. Joint EEA-FOEN report. Kopenhagen. $=$ EEA Report 11/2016.

Ewing, R.; Bartholomew, K.; Winkelman, S.; Walters, J.; Chen, D. (2008): Growing cooler. The evidence on urban development and climate change. Washington, DC. 
Fertner, C.; Jorgensen, G.; Sick Nielsen, T.A.; Nillson, K.S.B. (2016): Urban sprawl and growth management - drivers, impacts and responses in selected European and US cities. In: Future Cities and Environment 2, 9, 1-13. https://doi.org/10.1186/s40984-0160022-2

Fielding, A.J. (1982): Counterurbanisation in Western Europe. In: Progress in Planning 17, 1, 1-52. https://doi.org/10.1016/03059006(82)90006-X

Filion, P.; McSpurren, K.; Appleby, B. (2006): Wasted Density? The impact of Toronto's Residential-Density-Distribution Policies on Public-Transit Use and Walking. In: Environment and Planning A 38, 7, 1367-1392. https://doi.org/10.1068/a37414

Fina, S.; Planinsek, S.; Zakrzewski, P. (2009): Suburban crisis? Demand for single family homes in the face of demographic change. In: Europa Regional 17, 1, 2-14.

Fishman, R. (1987): Bourgeois utopias: The rise and fall of suburbia. New York.

Florida, R. (2017): The urban revival is over. In: New York Times, September, 1, 2017. https://www.nytimes.com/2017/09/01/opi nion/cities-suburbs-housing-crime.html (02.01.2018).

Frank, S. (2018): Inner-City Suburbanization - no Contradiction in Terms. Middle-Class Family Enclaves are Spreading in the Cities. In: Raumforschung und Raumordnung I Spatial Research and Planning 76, 2. https://doi.org/10.1007/s13147-016-0444-1

Frey, W.H. (1993): The New Urban Revival in the United States. In: Urban Studies 30, 4-5, 741-774. https://doi.org/10.1080/ 00420989320081901

Garcia-López, M.À.; Muñiz, I. (2010): Employment Decentralisation: Polycentricity or Scatteration? The Case of Barcelona. In: Urban Studies 47, 14, 3035-3056. https://doi.org/10.1177/ 0042098009360229

Gordon, D.L.A.; Janzen, M. (2013): Suburban nation? Estimating the size of Canada's suburban population. In: Journal of Architectural and Planning Research 30, 3, 197-220.

Gordon, P.; Cox, W. (2012): Cities in Western Europe and the United States: Do policy differences matter? In: The Annals of Regional Science 48, 2, 565-594. https://doi.org/10.1007/s00168011-0495-8

Grant, J.L.; Nelson, A.C.; Forsyth, A.; Thompson-Fawcett, M.; Blais, P.; Filion, P. (2013): The future of the suburbs. Suburbs in transition/The resettlement of America's suburbs/Suburbs in global context: the challenges of continued growth and retrofitting/ Suburban urbanity: re-envisioning indigenous settlement practices/Toward a new suburban America: will we catch the wave?/ Optimistic and pessimistic perspectives on the evolution of the North American suburb/Response: Suburbs in transition. In: Planning Theory and Practice 14, 3, 391-415. https://doi.org/10.1080/ 14649357.2013.808833

Guth, D.; Siedentop, S.; Holz-Rau, C. (2012): Erzwungenes oder exzessives Pendeln? Zum Einfluss der Siedlungsstruktur auf den Berufspendelverkehr. In: Raumforschung und Raumordnung 70, 6, 485-499. https://doi.org/10.1007/s13147-012-0196-5

Hall, P.; Pain, K. (2006): The polycentric metropolis. Learning from mega-city regions in Europe. London.

Harris, R. (2010): Meaningful Types in a World of Suburbs. In: Clapson, M.; Hutchison, R. (eds.): Suburbanization in global society. Bingley, 15-47.

Harris, R.; Larkham, P.J. (eds.) (1999): Changing Suburbs: Foundation, Form and Function. London. $=$ Studies in History, Planning and the Environment 24.

Häußermann, H.; Läpple, D.; Siebel, W. (2008): Stadtpolitik. Frankfurt am Main.

Helbich, M. (2012): Beyond Postsuburbia? Multifunctional Service Agglomeration in Vienna's Urban Fringe. In: Tijdschrift voor Economische en Sociale Geografie 103, 1, 39-52. https://doi.org/ 10.1111/j.1467-9663.2011.00673.x
Hesse, M.; Schmitz, S. (1998): Stadtentwicklung im Zeichen von „Auflösung“ und Nachhaltigkeit. In: Informationen zur Raumentwicklung 7/8, 435-453.

Hesse, M.; Scheiner, J. (2007): Suburbane Räume - Problemquartiere der Zukunft? In: Deutsche Zeitschrift für Kommunalwissenschaften 46, 2, 35-48.

Hesse, M.; Polívka, J.; Reicher, C. (2018): Spatially Differentiated, Temporally Variegated: The Study of Life Cycles for a Better Understanding of Suburbia in German City Regions. In: Raumforschung und Raumordnung I Spatial Research and Planning 76, 2. https://doi.org/10.1007/s13147-017-0511-2

Hilal, M.; Legras, S.; Cavailhès, J. (2018): Peri-Urbanisation: Between Residential Preferences and Job Opportunities. In: Raumforschung und Raumordnung I Spatial Research and Planning 76, 2, https://doi.org/10.1007/s13147-016-0474-8

Hirt, S. (2006): Post-Socialist Urban Forms: Notes from Sofia. In: Urban Geography 27, 5, 464-488. https://doi.org/10.2747/02723638.27.5.464

Hirt, S. (2012): Mixed Use by Default: How the Europeans (Don't) Zone. In: Journal of Planning Literature 27, 4, 375-393. doi: $10.1177 / 0885412212451029$

Hochstenbach, C.; Musterd, S. (2017): Gentrification and the suburbanization of poverty: changing urban geographies through boom and bust periods. In: Urban Geography. https://doi.org/10.1080/ 02723638.2016 .1276718

Jessen, J.; Roost, F. (eds.) (2015): Refitting Suburbia. Erneuerung der Stadt des 20. Jahrhunderts in Deutschland und den USA. Berlin.

Johansson, M.; Rauhut, D. (2002): The spatial effects of demographic trends and migration. ESPON project 1.1.4. Stockholm.

Kabisch, N.; Haase, D. (2011): Diversifying European agglomerations: evidence of urban population trends for the 21st century. In: Population, Space and Place 17, 3, 236-253. https://doi.org/10.1002/ psp. 600

Keil, R. (ed.) (2013): Suburban constellations: governance, land, and infrastructure in the $21^{\text {st }}$ century. Hamburg.

Klausen, J.E.; Røe, P.G. (2012): Governance and change on the urban fringe - special issue of Urban Research \& Practice. In: Urban Research and Practice 5, 1, 1-5. https://doi.org/10.1080/17535069. 2012.656445

Knapp, W.; Volgmann, K. (2011): Neue ökonomische Kerne in nordrhein-westfälischen Stadtregionen: Postsuburbanisierung und Restrukturierung kernstädtischer Räume. In: Raumforschung und Raumordnung 69, 5, 303-317. https://doi.org/10.1007/s13147011-0112-4

Kneebone, E.; Garr, E. (2010): The Suburbanization of Poverty: Trends in Metropolitan America, 2000 to 2008. Washington, DC.

Kneebone, E.; Nadeau, C.A. (2015): The Resurgence of Concentrated Poverty in America: Metropolitan Trends in the 2000s. In: Anacker, K.B. (ed.) The New American Suburb. Poverty, Race and the Economic Crisis. Farnham, 15-38.

Kloosterman, R.C.; Musterd, S. (2001): The Polycentric Urban Region: Towards a Research Agenda. In: Urban Studies 38, 4, 623633. https://doi.org/10.1080/00420980120035259

Krehl, A.; Siedentop, S.; Taubenböck, H.; Wurm, M. (2016): A Comprehensive View on Urban Spatial Structure: Urban Density Patterns of German City Regions. In: International Journal of GeoInformation 5, 6, 76, 1-21. https://doi.org/10.3390/ijgi5060076

Kuhn, G. (2002): Suburbanisierung: Das Ende des suburbanen Zeitalters? In: Informationen zur Modernen Stadtgeschichte 2, 5-12.

Le Galès, P.; Zagrodzki, M. (2006): Cities are back in town: the US/ Europe comparison. Paris. = Cahier Européen numéro 05/06 du Pôle Ville/métropolis/cosmopolis, Centre d'Etudes Européennes de Sciences Po.

Leinberger, C.B. (2008): The Next Slum? In: The Atlantic Monthly, March 2008. https://www.theatlantic.com/magazine/archive/ 2008/03/the-next-slum/306653/ (02.01.2018). 
Maciag, M. (2017): Population Growth Shifts to Suburban America. In: Governing Magazine. http://www.governing.com/topics/ urban/gov-suburban-population-growth.html (02.01.2018):

Mazierska, E.; Rascaroli, L. (2003): From Moscow to Madrid: Postmodern Cities, European Cinema. London.

Modarres, A.; Kirby, A. (2010): The suburban question: Notes for a research program. In: Cities 27, 2, 114-121. https://doi.org/10.1016/ j.cities.2009.11.009

Mumford, L. (1921): The Wilderness of Suburbia. In: The New Republic, September 7, 1921, 44-45.

Muñiz, I.; Garcia-López, M.À.; Galindo, A. (2008): The Effect of Employment Sub-centres on Population Density in Barcelona. In: Urban Studies 45, 3, 627-649. https://doi.org/10.1177/00420980070 87338

Nelson, A.C. (2013): The resettlement of America's suburbs. In: Planning Theory and Practice 14, 3, 392-403. https://doi.org/10.1080/ 14649357.2013.808833

Nicolaides, B. (2006): How hell moved from the city to the suburbs. In: Kruse, K.M.; Sugrue, T.J. (eds.): The new suburban history. Chicago, 80-98.

Nijman, J. (2015): North American suburbia in flux. Introduction. In: Environment and Planning A 47, 3-9. https://doi.org/10.1068/ a4701ge

Nüssli, R.; Schmid, C. (2016): Beyond the Urban-Suburban Divide: Urbanization and the Production of the Urban in Zurich North. In: International Journal of Urban and Regional Research 40, 3, 679-701. https://doi.org/10.1111/1468-2427.12390

OECD - Organisation for Economic Co-operation and Development (2017): The Governance of Land Use in OECD Countries. Policy Analysis and Recommendations. Paris.

Petsimeris, P. (2002): Population deconcentration in Italy, Spain and Greece: A first comparison. In: Ekistics 69, 412/413/414, 163172.

Phelps, N. (2017): Introduction: Old Europe, New Suburbanization? In: Phelps, N. (ed.): Governance, Land, and Infrastructure in European Suburbanization. Toronto, 3-17.

Phelps, N.; Parsons, N.; Ballas, D.; Dowling, A. (eds.) (2006): PostSuburban Europe: Planning and Politics at the Margins of Europe's Capital Cities. Houndmills, Basingstoke.

Phelps, N.A.; Wood, A.M.; Valler, D.C. (2010): A Postsuburban World? An Outline of a Research Agenda. In: Environment and Planning A 42, 2, 366-383. https://doi.org/10.1068/a427

Randolph, B.; Tice, A. (2017): Relocating Disadvantage in Five Australian Cities: Socio-spatial Polarisation under Neo-liberalism. In: Urban Policy and Research 35, 2, 103-121. https://doi.org/10. 1080/08111146.2016.1221337

Ravetz, J.; Fertner, C.; Sick Nielsen, T. (2013): The Dynamics of PeriUrbanization. In: Nilsson, K.; Pauleit, S.; Bell, S.; Aalbers, C. (Hrsg.): Peri-urban futures: Scenarios and models for land use change in Europe. Berlin/Heidelberg,13-44.

Rérat, P. (2012): The New Demographic Growth of Cities: The Case of Reurbanisation in Switzerland. In: Urban Studies 49, 5, 11071125. https://doi.org/10.1177/0042098011408935

Richardson, H.W.; Bae, C.-H.C. (eds.) (2004): Urban Sprawl in Western Europe and the United States. Aldershot.

Riguelle, F; Thomas, I.; Verhetsel, A. (2007): Measuring urban polycentrism: a European case study and its implications. In: Journal of Economic Geography 7, 2, 193-215. https://doi.org/10.1093/ jeg/lb1025

Salet, W.; Savini, F. (2015): The political governance of urban peripheries. In: Environment and Planning C 33, 3, 448-456. https://doi. org/10.1177/0263774X15594052

Salvati, L.; Carlucci, M. (2015): Land-use structure, urban growth, and periurban landscape: a multivariate classification of the European cities. In: Environment and Planning B 42, 5, 801-829. https://doi. org/10.1068/b120059p

Salvati, L.; Morelli, V.G. (2014): Unveiling Urban Sprawl in the Mediterranean Region: Towards a Latent Urban Transformation?
In: International Journal of Urban and Regional Research 38, 6, 1935-1953. https://doi.org/10.1111/1468-2427.12135

Salvati, L.; Morelli, V.G.; Rontos, K.; Sabbi, A. (2013): Latent Exurban Development: City Expansion Along the Rural-To-Urban Gradient in Growing and Declining Regions of Southern Europe. In: Urban Geography 34, 3, 376-394. https://doi.org/10.1080/ 02723638.2013.778675

Schmidt, S.; Fina, S.; Siedentop, S. (2015): Post-socialist Sprawl: A Cross-Country Comparison. In: European Planning Studies 23, 7 , 1357-1380. https://doi.org/10.1080/09654313.2014.933178

Schwanen, T.; Dieleman, F.M.; Dijst, M. (2004): The impact of metropolitan structure on commute behaviour in the Netherlands: a multilevel approach. In: Growth and Change 35, 3, 304333. https://doi.org/10.1111/j.1468-2257.2004.00251.x

Seidel-Schulze, A.; Dohnke, J.; Häußermann, H. (2011): Segregation, Konzentration, Polarisierung - sozialräumliche Entwicklung in deutschen Städten 2007-2009. Berlin. = Difu-Impulse 4.

Siedentop, S. (2015): Suburbane Räume unter Anpassungsdruck - Ein deutsch-amerikanischer Vergleich. In: Jessen, J.; Roost, F. (eds.): Refitting Suburbia. Erneuerung der Stadt des 20. Jahrhunderts in Deutschland und den USA. Berlin, 23-42.

Siedentop, S.; Fina, S. (2012): Who sprawls most? Exploring the patterns of urban growth across 26 European countries. In: Environment and Planning A 44, 11, 2765-2784. https://doi.org/10.1068/ a 4580

Siedentop, S.; Kausch, S.; Einig, K.; Gössel, J. (2003): Siedlungsstrukturelle Veränderungen im Umland der Agglomerationsräume. Bonn. = Bundesamt für Bauwesen und Raumordnung, Forschungen 114.

Siedentop, S.; Zakrzewski, P.; Stroms, P. (2018): A childless urban renaissance? Age-selective patterns of population change in North American and German Metropolitan areas. In: Regional Studies, Regional Science 5, 1, 1-20. https://doi.org/10.1080/21681376. 2017.1412270

Sieverts, T. (1997): Zwischenstadt: Zwischen Ort und Welt, Raum und Zeit, Stadt und Land. Braunschweig. = Bauwelt-Fundamente 118.

Silverstone, R. (ed.) (1997): Visions of suburbia. London/New York.

Sohmer, R.R.; Lang, R.E. (2001): Downtown Rebound. Washington, DC. $=$ Fannie Mae Foundation Census Note 3.

Taylor, L. (2011): No boundaries: exurbia and the study of contemporary urban dispersion. In: GeoJournal 76, 4, 323-339. https://doi. org/10.1007/s10708-009-9300-y

Thierstein, A.; Lüthi, S.; Kruse, C.; Gabi, S.; Glanzmann, L. (2008): Changing Value Chain of the Swiss Knowledge Economy: Spatial Impact of Intra-firm and Inter-firm Networks within the Emerging Mega-City Region of Northern Switzerland. In: Regional Studies 42, 8, 1113-1131. https://doi.org/10.1080/00343400802154557

Turok, I.; Mykhnenko, V. (2007): The trajectories of European cities, 1960-2005. In: Cities 24, 3, 165-182. https://doi.org/10.1016/j. cities.2007.01.007

Turok, I.; Mykhnenko, V. (2008): Resurgent European cities? In: Urban Research and Practice 1, 1, 54-77. https://doi.org/10.1080/ 17535060701795363

Walks, A. (2013): Suburbanism as a Way of Life, Slight Return. In: Urban Studies 50, 8, 1471-1488. https://doi.org/10.1177/ 0042098012462610

Wilson, S.G.; Plane, D.A.; Mackun, P.J.; Fischetti, T.R.; Goworowska, J. (2012): Patterns of Metropolitan and Micropolitan Population Change: 2000 to 2010. Washington, DC.

Wolff, M.; Haase, A.; Haase, D.; Kabisch, N. (2017): The impact of urban regrowth on the built environment. In: Urban Studies 54, 12, 2683-2700. https://doi.org/10.1177/0042098016658231

Wolff, M.; Wiechmann, T. (2017): Urban growth and decline: Europe's shrinking cities in a comparative perspective 1990-2010. In: European Urban and Regional Studies. https://doi.org/10. $1177 / 0969776417694680$ 
Ye, L.; Mandpe, S.; Meyer, P.B. (2005): What Is "Smart Growth?" Really? In: Journal of Planning Literature 19, 3, 301-315. https:// doi.org/10.1177/0885412204271668 